\title{
HTLV-1 Tax1 represses the proapoptotic protein Bim, which is crucial for T-cell transformation
}

\author{
Masaya Higuchi", Masahiro Fujii \\ From 15th International Conference on Human Retroviruses: HTLV and Related Viruses \\ Leuven and Gembloux, Belgium. 5-8 June 2011
}

Human $\mathrm{T}$ cell leukemia virus type 1 (HTLV-1) is an etiological agent of adult T-cell leukemia (ATL) and its viral oncoprotein Tax1 plays critical roles in $\mathrm{T}$ cell transformation and ATL development. Tax1 converts a T-cell line CTLL-2 from IL-2 dependent growth into IL-2-independent one, and the conversion requires inhibition of apoptosis. In this study, we investigated the involvement of Bim, an apoptosis inducer after cytokine deprivation, in Tax1-induced transformation. Bim expression is strongly induced in CTLL-2 cells after IL2 starvation, whereas such induction is markedly reduced in CTLL-2 cells transformed by Tax1. A Tax1 mutant defective of NF-kB2 activation transformed CTLL-2 less efficiently than wild type Tax, but this low transforming activity was rescued by knockdown of Bim in CTLL-2, suggesting that activation of noncanonical NF-kB2 pathway is involved in Tax1-mediated Bim repression. Furthermore, the expression of Bim was lower in HTLV-1 transformed and ATL cell lines than HTLV-1-negative T-cell lines. These results suggest that the Bim repression by Tax 1 is crucial for the survival of HTLV-1 infected cells and may play a role in ATL development.

Submit your next manuscript to BioMed Central and take full advantage of:

- Convenient online submission

- Thorough peer review

- No space constraints or color figure charges

- Immediate publication on acceptance

- Inclusion in PubMed, CAS, Scopus and Google Scholar

- Research which is freely available for redistribution 